не проходят тест 3 НО по физике и математике. Кроме этого, увеличивается прочент работ, которые выполнены очень хорошо (более 190 баллов), но в то же время средний балл не имеет четких положительных или отрицательных тенденций по физике или математике. Важными и тревожными являются показатели процента участников ЗНО, которые не проходят тестирование по физике и математике. Так, последние 3 года являются худшими как для математики, так и для физики по этому показателю, который вырос примерно в 2 раза. Обнаружено, что участники ЗНО по физике и математике, в последние годы сильнее расслаиваются на две группь: те, что знают материал очень хорошо, и те, кто его знает плохо. Соответственно из этих данных можно сделать вывод о необходимости усиления внимания к обучению учашихся по физике и математике в учебных заведениях.

Ключевые слова: качество образования, уровень знаний, физика, математика, внешнее независимое оценивание (ВНО), анализ данных.

BYKovSKIY Y. T. Comparative analysis of the modern state of educational results of students in physics and mathematics: 2008-2018.

In this article attention is focused on the issue of estimation of education quality. A comparative analysis of the current level of educational level of students in physics and mathematics in the period from 2008 to 2018 based on the results of external independent evaluation (EIE) is presented.

Particular attention is paid to analysis of the changes and correlation of student results in coverage of external independent evaluation in physics and mathematics; mean score dynamics; the percentage of test participants who make a test on physics and mathematics for 190 or more points, as well as those that do not pass it.

Keywords: quality of education, level of knowledge, physics, mathematics, external independent evaluation (EIE), data analysis.

DOI: https://doi.org/10.31392/NZ-npu-142.2019.05

УДК 378.091.3-051:780.614.331]:17

Буханєеич В. В.

\title{
ЗАБЕЗПЕЧЕННЯ ГЕДОНІСТИЧНОГО КОМПОНЕНТА ЯК УМОВА ІНТЕНСИВНОГО НАВЧАННЯ СКРИПАЛЯ-ПОЧАТКІВЦЯ
}

У статті розглянуті поняття "гедонізм" як етичне вчення i “гедоністичне начало психіки" як феномен, щу є основою психологічного розвитку людини, прогресуючого від елементарних "приємно - неприсмно" до понять "добро - зло" . Висвітлено умови, при яких з'являсться відчуття задоволення від навчання гри на скрипиі на початковому етапі, а також методи $і$ способи, що допомагають виконати иі умови на практиці. Розглянуто поняття "гедоністичний еталон". Описано умови вироблення ігрових рухів через механізм підкріплення, як один із способів, що забезпечує комфортний психологічний фон $і$ сприяє швидкому та ефективному освоєнню скрипалем-початківцем фізичних навичок. Розглянуто способи забезпечення психологічного відчуття успішності навчальних дій через пластичне оцінювання, сугестію, фіксацію результатів та констатацію учнем свого музичного зростання. Описано умови, щуо надають можливість забезпечити сочіальне схвалення результатів навчання скрипаля-початківия. Висвітлено чинники, що забезпечують активізацію потреби в навчанні гри на скрипці.

Більшого ефекту в навчанні можна досягти, підсилюючи ті елементи поведінки, які 
потрібні для пізнавальної діяльності, $і$ при умові, щуо позитивне підкріплення переважатиме протягом заняття, безперечно виникне відповідний емоційний фон навчання.

Для забезпечення гедоністичного компонента навчання потрібно: створити умови для сочіального схвалення його результатів, забезпечити відчуття успішності навчальних дій учня, активізувати потребу в освоєнні скрипки.

Результати дослідження дають змогу стверджувати, що впровадження у навчальний процес запропонованих методів та прийомів сприяе інтенсифікації навчання гри на скрипиі дітей дошкільного та молодшого шкільного віку.

Ключові слова: гедоністична складова, інтенсивне початкове навчання, гра на скрипці, дошкільний та молодший шкільний вік.

Інтенсивне навчання потребує досить великих енергетичних затрат організму як учня, так і вчителя, а освоєння музичного інструменту є процесом довготривалим i складним. Виникає питання: як можна забезпечити психологічну витривалість дитини в такому "марафонському" процесі навчанні гри на скрипці? 3 одного боку, велику роль відіграє фрормування та збереження мотивації навчання, але для дитини 5-9 років, на наш погляд, цього компонента буде недостатньо, оскільки психіка дитини дуже рухлива і її потреби швидко змінюються. Тому потрібно знайти такий фрактор у навчанні, який би дав можливість підтримувати позитивний психологічний фон протягом тривалого часу.

На наш погляд, позитивну роль може зіграти гедоністичний компонент навчання, заснований на гедоністичному началі психіки людини, який знаходить відображення і в освітньому процесі зокрема.

Сучасна педагогіка та психологія досліджує різноаспектні явища і тенденції навчання дітей дошкільного та молодшого шкільного віку. Зокрема, скрипкова педагогіка має значні здобутки у сфері скрипкового навчання (М. Берлянчик, Т. Єзерська, К. Завалко, І. Сташевська В. Стеценко та ін.). Гедоністичний принцип навчання висвітлений в дослідженнях Д. Колесова, І. Малашевської, Т. Строгаль та ін. [1; 4; 7]. Проте врахування гедоністичного начала в психічному бутті людини не знайшли свого належного узгодження в системі проблем скрипкової педагогіки. Аналіз сучасної теорії і практики позашкільної освіти засвідчив, що проблема навчання, зокрема скрипкового, спрямованого на забезпечення гедоністичного компонента, ще не була предметом спеціального психолого-педагогічного дослідження.

Отже, метою cmammi $є$ розкриття методики забезпечення гедоністичного компонента навчання скрипаля-початківця.

Гедонізм (від грецьк. hedone - насолода, задоволення) - етичний принцип, відповідно до якого вищою метою і основним мотивом поведінки людини $\epsilon$ насолода, задоволення. Ми будемо розглядати гедоністичний компонент не як спрямованість на задоволення в навчанні, а як ґрунтовну основу людської психіки, яка в принципі направлена на отримання приємних відчуттів від задоволення потреб. Гедонізм, як етичне вчення, "не враховує, що приємне це лише оцінка успішності задоволення потреби... Все психічне починається 3 оцінки, яка має гедоністичний тон" $[1$, с. 86].

Первинним гедоністичним підґрунтям розвитку психіки можна назвати розрізнення відчуття “приємно - неприємно", потім до цього приєднується здатність розрізняти “добре - погано”, а потім - розрізнення “добро - зло" (що 
властиво тільки людині) [2].

У людей ланцюги задоволення тісно пов'язані зі структурами мозку, які відповідають за прийняття рішень, планування, емоції і пам'ять, тобто таких, що безпосередньо впливають на інтенсивність навчання. Коли якесь переживання здається нам приємним, воно запускає кілька процесів різної тривалості: а) нам подобається досвід (безпосереднє відчуття задоволення), б) ми пов'язуємо зовнішні сенсорні стимули (вид, звуки, аромати тощо) і внутрішні стимули (наші думки і почуття в цей час) 3 пережитим приємним досвідом, і ці асоціації дають нам змогу зрозуміти, що потрібно зробити, щоб ще раз пережити приємні відчуття; в) ми присвоюємо цьому приємному переживанню певну цінність (високу або низьку), щоб у майбутньому вибирати з різних задоволень найбільш прийнятне, залежно від того, скільки зусиль ми готові докласти і на які ризики згодні піти [3, с. 35].

Кожна дитина отримує задоволення від перших занять. Згодом, це відчуття втрачається, перетворюючись, як правило, в навчання за вимогою. Об'єктивні причини: труднощі в освоєнні інструменту та вивчення музичної грамоти, необхідність нескінченних повторів для закріплення навичок - відомі. Але спочатку дитина намагається їх долати з ентузіазмом. Що ж відбувається в подальшому? Однією з причин можна назвати той фракт, що дитині потрібно вийти за рамки зони психологічного комфорту та вона не завжди може досягти очікуваного гедоністичного еталону при подоланні труднощів навчання гри на скрипці.

Гедоністичний еталон - визначення ступеня задоволення проблеми, відчутого індивідом (під час задоволення потреби) і зафріксованого в центральній нервовій системі рівня приємного, який на майбутнє стає для нього критерієм повноти та ефективності задоволення цієї потреби. Людина починає орієнтуватися на досягнутий рівень приємного, і якщо останній опиниться нижче очікуваного, - вона буде задоволена неповністю [1].

Вищий, ніж раніше, рівень приємного досягнутий людиною при задоволенні певної потреби, замінює колишній, менш високий, і фіксується в якості нового гедоністичного еталона. Після цього, в своїй діяльності людина починає орієнтуватися вже на цей стандарт, прагнучи не опускатися нижче. Це зумовлено природними механізмами приємного, як такого, що сприяє життю і неприємного - того, що життю перешкоджає. Тому орієнтація на приємне і прагнення уникнути неприємного закладені в самій природі живого. А гедоністичний еталон слугує орієнтиром в цьому прагненні до більшої стійкості в житті.

На думку Д. Колесова, існують три закони дії гедоністичних еталонів в житті людини: закон підвищення, закон насичення та закон адаптації. Як життєвий результат фріксується саме те, що супроводжується приємним, яким індивід самостверджується. Неприємне не може бути способом самоствердження - тільки сигналом до зміни характеру дій, до відмови від того, що спочатку було прийнято людиною як життєво корисне, але виявилося помилковим. Отже, приємний стан - фіксується, а неприємний розряджається в зусиллях по досягненню приємного. При цьому про неприємний частіше згадують як про те, що було подолано.

Оцінка успішності не є збудником для задоволення потреби, а лише 
“залишком" збудження, що виникає при виникненні потреби. Відомо, що, чим більше людина чогось прагне, тим більше вона задоволена, якщо це отримає (або цього досягає). Відповідно, навіть за нейрофізіологічним механізмом приємність випливає з факту задоволення потреби [1].

Таким чином, педагогу потрібно враховувати цю особливість людської психіки, оскільки зовнішня успішність дії учня ще не $є$ повне задоволення його внутрішньої потреби. Потрібно враховувати рівень задоволеності дитини своїми вміннями, стимулюючи її прагнення до нових досягнень, до подальшого самоствердження як особистості через прищеплення любові до музики, створення умов для отримання задоволення від процесу музикування, формування і розвиток музичних здібностей та навичок гри на інструменті. Для цього, на нашу думку, необхідно забезпечити відчуття успішності навчальних дій учня, створити умови для соціального схвалення результатів навчання, активізувати потребу в освоєнні скрипки.

Для соціального схвалення результатів навчання важливо створити ситуацію сценічного успіху дитини в учбовому закладі. Для цього потрібно правильно підібрати репертуар виступу, забезпечити відповідний художній та технічний рівень виконання, допомогти учневі психологічно налаштуватись на публічний показ музичних творів.

Вдалий сценічний виступ - це найбільш складний для досягнення і вагомий для особистості вид соціального схвалення. Раннє включення учня в концертні виступи в складі дитячого інструментального колективу створює умови для такого визнання вже на початковому етапі навчання. Ансамблеве музикування $€$ одним із найпростіших засобів самоствердження і отримання задоволення від музикування для скрипаля-початківця.

Також важливим в житті дитини є участь в музичній частині шкільних та домашніх сімейних свят та інших заходів з можливістю публічного виконання музичних творів на скрипці. Викладачу потрібно проводити бесіди з батьками щодо організації та проведення подібних заходів, в яких скрипаль-початківець міг би продемонструвати свої успіхи та отримати підтримку оточуючих; забезпечити відповідний репертуар, цифровий або інший вид супроводу для більш яскравого звучання скрипкових творів.

Найбільш важливим гедоністичним компонентом навчання є забезпечення психологічного відчуття його успішності. Безперечно, в процесі навчання потрібно виробляти в учня усвідомлене ставлення до занять, але саме на початковому його етапі в досить ранньому віці, на наш погляд, для досягнення психологічного комфорту та відчуття успішності, на заняттях потрібно використовувати вже відомі ефективні механізми керування роботою психіки. Наприклад, доречним буде використання закономірностей, описаних в роботах дослідників біхевіориського підходу до навчання. Одним із фундаментальних механізмів, які дають змогу впливати на поведінку людини, є підкріплення, яке сприяє більш повному, відчуттю задоволенню потреби.

Система заохочень та покарань задіяна у вихованні людини з давніх часів. Але ця система починає діяти переважно вже після здійснення поведінкових дій, на які вона має впливати, тому вона працює скоріше з пам'яттю та уявою. Підкріплення $є$ таким тільки тоді, коли надається саме в момент поведінкової дії. Підкріплення - мережа, складена з трьох окремих компонентів: заохочення 
(чуттєве задоволення, яке можна описати словом “подобається"), бажання (мотивація до підкріплення) і знання про майбутні заохочення, що включають в себе асоціації, уявлення про минулі підкріплення - на них ґрунтується передчуття підкріплень майбутніх.

Згідно з дослідженнями сучасних учених, зокрема В. Сузукі, підкріплення, пов'язане з навчанням, реалізується двома областями мозку: гіппокампом і мозжечковою мигдалиною (гіпокамп відіграє важливу роль у формуванні нових асоціацій, а мигдалина мозочка відкладає емоційні спогади, включаючи і ті, що пов'язані з досвідом отримання сильного задоволення) [6]. Але на питання, чим конкретно займаються центри задоволення (просто "кодують" задоволення або частково самі викликають це відчуття), відповіді досі немає. Вчені й донині не зуміли до кінця зрозуміти, як саме мозок генерує відчуття задоволення.

Людині властиве підсилення поведінки, що викликає схвалення під час поведінкового акту (тобто підкріплення) і навпаки, згасання непідкріпленої поведінки. Таким чином, більшого ефекту в навчанні можна досягти, підсилюючи ті елементи поведінки, які потрібні для пізнавальної діяльності, і при умові, що позитивне підкріплення переважатиме протягом заняття, безперечно виникне відповідний емоційний фон навчання [5].

На початковому етапі формування навички важливі одні підкріплення; на наступному, коли навик вже майже сфрормований - інші; етап шліфування майстерності вимагає відмінної форми підтримки. Початківець потребує як моральної, так і інформаційної підтримки. Як що позитивно підкріплювати навіть самі незначні кроки - це тільки надихне його на подальшу роботу. Надалі, коли навик вже освоєно, потрібно переходити до іншого типу підкріплення, яке називається варіабельним і здійснюється нерегулярно, в довільному порядку. Ф. Майленова зазначає, що варіабельний режим для вже вивченої поведінки більш ефективний, ніж постійний, передбачуваний.

Причину ефективності такого впливу дослідниця вбачає в "особливостях нашого мислення, яке завжди прагне відгадувати загадки, а якщо схема надто проста і зрозуміла, їй просто "нецікаво" стає слідувати. Ця особливість нашої психіки використовується в азартних іграх. Гравці ніколи не знають напевно, виграють вони або програють, і чим довший інтервал між підкріпленнями у варіативному режимі, тим сильніше він стимулює поведінку.

Навчаючись з бажанням і задоволенням, можна подолати безліч перешкод (зокрема так звану відсутність здібностей) за допомогою внутрішніх резервів, доступ до яких можливий лише через радість. Для людини навчання $\epsilon$ однією 3 нагальних потреб, отже найважливіше - не погасити той вогник цікавості, подиву і радості, яким супроводжується навчання всього нового, і постаратися підтримувати його протягом всього процесу навчання.

За допомогою професійного планування занять та використання підкріплення можливо позбавитися нудьги та значно прискорити освоєння фрізичних навичок, що потребують багаторазових одноманітних повторів через потребу тренажу м'язової пам'яті, яка має досить велику інерцію. Умовами вироблення певної м'язової навички є:

1. Поступове підвищення складності.

2. Доступність завдань. В учня завжди має бути реальна можливість зробити необхідне і отримати підкріплення. 
3. Використання підкріплення для поточного (а не ідеального) рівня оволодіння навичкою.

4. В окремому проміжку часу потрібно вирішувати лише одне конкретне завдання, намагатись не розпилювати увагу на формування двох або більше навичок одночасно. При виконанні нового завдання, необхідне тимчасове зниження уваги до рівня якості навичок, засвоєних раніше.

5. Детальне планування навчання, щоб в разі раптового успіху учня, була готова програма подальших дій.

6. Змінення форми научіння при неуспішності наявної.

7. Закінчення кожного заняття позитивним підкріпленням (відсутність даної дії суб'єктивно відповідає покаранню).

Хочемо зауважити, що ці умови, допомагаючи створити відчуття задоволення від процесу навчання, також забезпечують виконання принципу послідовності навчання.

При правильній роботі м'язового апарату у скрипаля виникає відчуття задоволення від рухової діяльності, так звана "м'язова радість" - наслідок природного механізму вироблення "гормонів щастя" під час активної рухової діяльності [4, с. 69]. Отже, якість виконання фрізичних дій на інструменті потребує особливої уваги і при відповідній роботі педагога, що потребує урахування вікових та індивідуальних особливостей дитини в поясненні і веденні уроку, може також слугувати додатковим джерелом задоволення для учня.

Також можна говорити про випереджувальне (до початку дії і аж до його завершення) і завершальне (як його суб'єктивний результат) підкріплення. Випереджаючий тип підкріплення проявляється такими емоціями, як наснага, ентузіазм, упевненість в своїх силах, передчуття. Все це можливо тільки до моменту задоволення потреби і важливо для того, щоб довести справу до кінця. Завершальне підкріплення має інший характер: воно фіксує той факт, що в результаті дій було отримано саме те, що потрібно. Воно фріксує всю ту послідовність дій, яка привела до успішного результату - повного задоволення потреби. Цей характер завершального підкріплення властивий таким емоціям, як торжество, гордість, радість перемоги, "почуття добре зробленої справи", іноді - самовдоволення.

Для психологічного відчуття успішності навчальних дій потрібно оцінювання перевести з категорії "вироку, який не підлягає оскарженню" в категорію "констатації" рівня на даний момент, з можливістю цей рівень підвищити, виконавши певні умови. Яскравий приклад такого оцінювання описує в своїх працях видатний педагог В. Шаталов. Його учні мали можливість підвищити оцінку, пересклавши матеріал, що знімало психологічний тиск, та стимулювало учня до роботи над собою [8]. Також дитині важливо навіювати впевненість у власних можливостях. Це і вербальні установки і аудіо та відео фріксація результатів різних етапів навчання для порівняння та усвідомлення учнем власних досягнень.

Саме по собі задоволення від навчання не сприятиме його інтенсифрікації, якщо не буде забезпечена потреба в діях, що викликають це задоволення. Таким чином, необхідно активізувати потребу в навчанні гри на скрипці. Одним із засобів досягнення є організація дозвілля, надихаючого до музикування 
(відвідування зустрічей з цікавими людьми, музикантами різного віку, сімейне музикування, залучення дитини як музиканта до організації та проведення різних заходів). Цікавим в цьому є досвід відомого науковця і педагога-практика С. О. Мільтоняна, який разом з однодумцями організував сімейний клуб в м. Тверь, де діти та батьки мали можливість реалізувати описані вище ідеї на практиці і результати такого експерименту виявились дуже позитивними. Останнім часом популярності набувають літні скрипкові табори, де діти декілька тижнів живуть, “занурюючись” в музику, маючи можливість жити повноцінним життям музиканта, що також сприяє інтенсифікації їх музичного і скрипкового розвитку. Пропагування музикування на інструменті через організацію концертів з яскравих творів за участю талановитих учнів також сприяє виникненню та збереженню потреби в навчанні гри на скрипці.

Таким чином, для забезпечення гедоністичного компонента навчання потрібно: створити умови для соціального схвалення його результатів, забезпечити відчуття успішності навчальних дій учня, активізувати потребу в освоєнні скрипки.

Результати дослідження дають змогу стверджувати, що впровадження у навчальний процес запропонованих методів та прийомів сприяє інтенсифікації навчання гри на скрипці дітей дошкільного та молодшого шкільного віку.

\section{Використана література:}

1. Колесов Д. Б. Понятие гедонического эталона и гедонизм как этическое учение. Развитие личности. (Проблемы бытия личности). 2002. № 1. С. 85-94.

2. Колесов Д. Б. Уровни, виды и модальность подкрепления. Развитие личности. Проблемы бытия личности. № 2. 2002. С. 13-20. Ел.ресурс.

3. Линден Д. Мозг и удовольствия / пер. с англ. И. Веревкиной. Москва : Эксмо, 2012. 288 с.

4. Малашевська I. А. Гедоністичний принцип музичного навчання дошкільників i молодших школярів із використанням музикотерапії. Педагогічні науки. 2014. № 61-62. С. 65-71.

5. Майленова Ф.Г. Влияние эмоций на качество обучения. Принцип позитивного подкрепления [Электронный ресурс]. Информационный гуманитарный портал "Знание. Понимание. Умение". № 2. 2010. Педагогика. Психология. ULR : http://www.zpu-journal.ru/e-zpu/2010/2/M ailenova/

6. Сузуки В. Странная девочка, которая влюбилась в мозг. Как знание нейробиологии помогает стать привлекательнее, счастливее и лучше. Москва : “Альпина Паблишер", 2017. 304 с.

7. Строгаль Т. Ю. Формування емоційно-естетичного досвіду підлітків на уроках музики : автореферат дис. ... канд. пед. наук : 13.00 .02 - теорія та методика музичного навчання ; Нац пед. ун-т ім. М. П. Драгоманова. Київ, 2018. 21 с.

8. Шаталов В.Ф. Куда и как исчезли тройки. Из опыта работы школ Донецка / предисл. В. В. Давыдова. Москва : “Педагогика”, 1979. 134 с.

\section{References:}

[1] Kolesov, D. B. (2002) Ponyatie gedonicheskogo etalona i gedonizm kak eticheskoe uchenie. Razvitie lichnosti. (Problemy bytiya lichnosti). № 1, S. 85-94.

[2] Kolesov, D. B. (2002) Urovni, vidy i modalnost podkrepleniya. Razvitie lichnosti. Problemy bytiya lichnosti. № 2, S. 13-20. El.resurs

[3] Linden, D. (2012) M ozg i udovolstviya / per. s angl. I. V erevkinoj. M oskva : Eksmo, 288 s.

[4] Malashevska, I. A. (2014) Hedonistychnyi pryntsyp muzychnoho navchannia doshkilnykiv i molodshykh shkoliariv iz vykorystanniam muzykoterapii. Pedahohichni nauky, № 61-62, S.65-71.

[5] Majlenova, F. G. (2010) V liyanie emocij na kachestvo obucheniya. Princip pozitivnogo podkrepleniya [Elektronnyj resurs]. Informacionnyj gumanitarnyj portal "Znanie. Ponimanie. Umenie". № 2. Pedagogika. Psihologiya. ULR : http://www.zpu-journal .ru/e-zpu/2010/2/M ailenova/

[6] Suzuki, V. (2017) Strannaya devochka, kotoraya vlyubilas v mozg. Kak znanie nejrobiologii pomogaet 
stat privlekatelnee, schastlivee i luchshe. M oskva: "A Ipina Pablisher", $304 \mathrm{~s}$.

[7] Strogal, T.Yu. (2018) Formuvannya emocijno-estetichnogo dosvidu pidlitkiv na urokah muziki: avtoreferat dis. ... kand. ped. nauk : 13.00 .02 - teoriya ta metodika muzichnogo navchannya; Nac ped. un-t im. M. P. Dragomanova. Kiyiv, $21 \mathrm{~s}$.

[8] Shatalov, V.F. (1979) Kuda i kak ischezli trojki. Iz opyta raboty shkol Donecka / predisl. V. V. Davydova. M oskva: "Pedagogika", 134 s.

\section{БУХАНЕВИч В.В. Обеспечение гедонистического компонента как условие} интенсивного обучения начинающего скрипача.

В статье рассмотрены понятия "гедонизм" как этическое учение и "гедонистическое начало психики" - феномен, являющийся основой психологического развития человека, прогрессирующего от элементарного "приятно-неприятно" до понятий " добро-зло" . Освещень условия, при которых появляется ощущение удовольствия от обучения игре на скрипке на начальном этапе, а также методы и способы, помогающие эти условия выполнить на практике. В общих чертах рассмотрено понятие "гедонистический эталон". Описаны условия выработки двигательных навыков через механизм подкрепления, как один из способов, обеспечиваюший комфортный психологический фон и способствуюший быстрому и эффективному освоению игровых движений начинающим скрипачом. Рассмотрены способы обеспечения психологического ощущения успешности учебных действий через пластичное оценивание, сугzестию, фиксаиию результатов и констатацию учеником своего музыкального роста. Описаны условия, позволяюшие обеспечить сочиальное одобрение результатов обучения начинающего скрипача. Освещены факторы, обеспечивающие активизацию потребности в обучении игре на скрипке.

Большего эффекта в обучении можно достичь, усиливая те элементы поведения, которые нужны для познавательной деятельности, и при условии, что положительное подкрепление будет преобладать в течение занятия, бесспорно возникнет соответствуюший эмочиональный фон обучения. Для обеспечения гедонистического компонента обучения нужно: создать условия для сочиального одобрения его результатов, обеспечить ощущение успешности учебных действий ученика, активизировать потребность в освоении скрипки.

Результаты исследования позволяют утверждать, что внедрение в учебный процесс предложенных методов и приемов способствует интенсификации обучения игры на скрипке детей дошкольного и младшего икольного возраста.

Ключевые слова: гедонистическая составляющая, интенсивное начальное обучение, игра на скрипке, дошкольный и младший школьный возраст.

BUKhANIEVYCH VIKTORIIA. Providing a hedonic component as a condition of intensive learning novice violinist.

The article discusses the concept of "hedonism" as an ethical doctrine and "hedonic beginning of the psyche" - phenomenon, which is the basis of the psychological development of a person, progressing from the elementary "pleasantly unpleasant" to the concepts of "good-evil". The conditions under which there appears a feeling of pleasure from learning to play the violin at the initial stage, as well as methods and methods that help to fulfill these conditions in practice, are highlighted. The concept of "hedonistic standard" is considered in general terms. The conditions for the development of motor skills through the reinforcement mechanism are described as one of the methods providing a comfortable psychological background and facilitating the quick and effective mastering of game movements by a beginner violinist. Ways to ensure the psychological sense of learning success through plastic assessment, suggestion, fixation of results and the student's statement of his musical growth are considered. The conditions are described that allow for social approval of the learning outcomes of a beginner violinist. Covered factors that enhance the need for learning to play the violin.

A greater effect in learning can be achieved by reinforcing those elements of behavior that are necessary for cognitive activity, and provided that positive reinforcement prevails during the lesson, a corresponding emotional background of learning will undoubtedly arise. To ensure the hedonistic component of instruction, it is necessary: to create conditions for the social approval of its results, to 
provide a sense of the success of the student's learning activities, to intensify the need for mastering the violin.

The results of the study suggest that the introduction of the proposed methods and techniques into the educational process helps to intensify the learning of the violin for children of preschool and primary school age.

Keywords: hedonistic component of education, intensive primary education, playing the violin, preschool and primary school age.

DOI: https://doi.org/10.31392/N Z-npu-142.2019.06

УДК 378.147

Гевко І. В.

\section{ЗАСТОСУВАННЯ КОМП'ЮТЕРНИХ ТЕХНОЛОГІЙ В ОСВІТНІЙ ПРОЦЕС ПІДГОТОВКИ В ЗАКЛАДАХ ВИЩОЇ ОСВІТИ}

У статті розглядаються основні поняття, щзо стосуються інформатизації сучасної освіти, показується роль комп юотерних технологій в підготовиі студентів. Розкрито вплив комп'ютерних технологій на підвищення якості освіти при застосуванні в професійній підготовиі студентів вищих навчальних закладів. Розглядаються основні поняття, щзо стосуються інформатизаиії сучасної украӥнської освіти, показується роль комп ютерних технологій в підготовичі студентів. Проведений аналіз сучасних поглядів на інформатизацію освіти як на процес його забезпечення методологією і практикою розробки та оптимального використання сучасних інформащійних технологій, орієнтованих на реалізацію психологопедагогічних иүілей навчання $i$ виховання. $B$ статті зазначається, щуо впровадження комп'ютерних технологій у сферу освіти слід розглядати як початок революиійного перетворення традиційних методів і технологій навчання галузі освіти загалом. Важливу роль на иььому етапі відіграють комунікаційні технології.

Також у статті є аналіз та висвітлення основних переваг та проблем, які виникають при використанні комп'ютерних технологій у навчальному прочесі, є окреслення моделі підготовки педагогічних працівників в умовах інформатизаиії суспільства.

В українському освітньому просторі на сьогодні склалися об'єктивні передумови для системного використання на заняттях комп'ютерних засобів в організації навчального процесу. У зв'язку з тим, щзо зміст підготовки студентів педагогічного вузу має складну $i$ багатокомпонентну структуру, відрізняється великою різноманітністю досліджуваних об 'єктів, явищ і процесів, важливо забезпечити, поряд з глибоким засвоєнням значного обсягу теоретичних знань, розвиток у них професійних компетенцій, в тому числі інформаційної, щзо дає змогу творчо використовувати отримані на навчальних заняттях знання в різних навчальних і професійних умовах.

Ключові слова: інформатизація освіти; інформаційні технологій; нові інформаційні технології, комп'ютерні технології, навчальний процес, компетентності.

Аналіз сучасних поглядів на інформатизацію освіти як на процес його забезпечення методологією i практикою розробки та оптимального використання сучасних інформаційних технологій, орієнтованих на реалізацію психолого-педагогічних цілей навчання і виховання, дає змогу стверджувати, що дотепер зберігає актуальність концепція інформатизації освіти, розроблена 